\title{
Integrated concurrent engineering teams for increased efficiency in flight projects (Erratum)
}

\section{Bert Pasquale}

Bert A. Pasquale, "Integrated concurrent engineering teams for increased efficiency in flight projects (Erratum)," Proc. SPIE 11450, Modeling, Systems Engineering, and Project Management for Astronomy IX, 1145030 (9 April 2021); doi: $10.1117 / 12.2598859$

SPIE. Event: SPIE Astronomical Telescopes + Instrumentation, 2020, Online Only 


\section{Integrated Concurrent Engineering Teams for Increased Efficiency in Flight Projects (Erratum)}

Bert Pasquale, NASA Goddard Space Flight Ctr. (United States)

Proceedings Volume 11450, Modeling, Systems Engineering, and Project Management for Astronomy IX;

1145018 (2020) https://doi.org/10.1117/12.2581066

Event: SPIE Astronomical Telescopes + Instrumentation, 2020, Online Only, United States

Online Publication Date: 14 December 2020

Erratum Published: 9 April 2021

Publisher's Note: This manuscript and video were originally published on 14 December 2020. The manuscript and video content and titles have been revised to reflect correct terminology. 